\title{
Potential Influences on the Prospect of Renewable Energy Development in OPEC Members
}

Hanan Alsadi ${ }^{1}$

\section{Introduction}

The global energy transitioning trend escalates due to the continuous growth of energy consumption and advancing climate change. While the total fossil fuel consumption is increasing twice as fast as the average rate over the last decade, making $70 \%$ of the global energy demand, the reckless use of fossil fuel is causing substantial damage to the environment (International Energy Agency, 2018; Šolc, 2013). An effective fix to the problem while dubious is to replace the energy source by alternatives. The renewable energy (RE) offers the most definite prospect for producing clean, sustainable power in substantial quantities, which arouses interest around the world. According to Gielen and Colleagues (2019), the RE's share of global consumption energy would rise from $15 \%$ in 2015 to $63 \%$ in 2050 .

However, if this increasing trend in renewable energies would also prevail among Organization of Petroleum Exporting Countries (OPEC), is subject to debate. They all have abundant potential to invest in renewable energy sources. Yet, some of the Middle Eastern and Arab Gulf OPEC members do not have or have a small amount of renewable energy sources. In contrast, other members have significant renewable energy sources.

Researchers have studied some aspects of renewable energy and its relationship to the OPEC countries. For example, Wittmann (2013) looked at the potential for transitioning from petroleum exportation to renewable energy exportation among the OPEC countries. Still, Wittmann does not explain any specific transition strategies or plans for the Middle Eastern OPEC countries. Romano and Scandurra (2014) studied investments in renewable energy infrastructure in the non-Middle Eastern OPEC countries. Thus, there is virtually no data on investments in Middle Eastern countries. Both Wittman (2013) and Romano and Scandurra (2014) noted two significant issues. First, OPEC is not monolithic. For them, it is a loose association of many different countries with two identifiable groups: non-Middle Eastern members who use some renewable energy and Middle Eastern members who do not use renewable energy sources. Secondly, the authors note that the Middle Eastern members do not have publicly available government policies

\footnotetext{
${ }^{1}$ Graduate Student Schar School of Policy and Government @ George Mason University; Teaching Assistant, International Affairs @ Qatar University Email: h.alsadi@qu.edu.qa
} 
for renewable energy. Therefore, what is true for OPEC members in South America or Africa may not be accurate for OPEC members in the Middle East and Gulf states.

Furthermore, Uduma and Arciszewski (2010) used the OPEC country of Nigeria for their review of the relationship of renewable energy to the country's internal economy. Additionally, Mezher, Dalwelbiat, and Abbas (2012) conducted a limited study of energy policy options for the United Arab Emirates (UAE). These authors compared the UAE's renewable energy policy to the policies of other countries. However, they do not directly link the UAE's approach to renewable energy to the key drivers that influence an OPEC country's decision to pursue renewable energy or not. Additionally, Atalay, Biermann, and Kalfagianni describe the influences of renewable energy policies in other countries on OPEC countries. The authors call the limitation of successful renewable energy policies "policy transfer." Atalay and Colleagues also identify that, although all Middle Eastern countries appear not to be pursuing renewable energy, within the Middle Eastern OPEC members, there are "leaders" (UAE) and "laggards" (Saudi Arabia and Oman). Lastly, few researchers examine the influence of renewable energy policies in non-OPEC countries and the declining oil reserves in the OPEC countries on the implementation of renewable energy technologies in the OPEC countries. For instance, Almansoori's work (2014) examines the link between the renewable energy policy of South Korea and the oil exports of OPEC countries. This article indicates that, in the short term, OPEC countries will continue to produce oil and not transition to renewable energy because the demand for their oil will increase. OPEC countries that do not depend on foreign aid will not transition to renewable energy sources as long as international demand for petroleum remains steady or increases.

The research is deficient in explaining why some OPEC members lag behind other members in their transition to renewable energy, including how Middle Eastern OPEC members are implementing renewable energy and how OPEC members view their shrinking oil reserves.

Thus, the purpose of this paper is to explore the influences on OPEC members that result in some OPEC members starting to adopt renewable energy and others have not started. The paper also investigates the relationship of the implementation of renewable energy policies in importing countries and the scarcity of crude oil reserves with the transition of renewable energy in the OPEC members. Besides, the paper proposes recommendations for those countries that are slow or reluctant to embrace renewable energy to achieve a transition from black to green. The main research question of this is: What makes some OPEC member states slowly begin to adopt renewable energies while others stay lagged? 
This paper is structured as follows: Section 2 presents the status of renewable energy development in OPEC countries. Section 3 examines the possible impact of nonOPEC members' renewable energy policies on the transition to renewable resources in OPEC members. Section 4 examines the likely impact of scarce oil reserves on the transition to renewable resources in OPEC members. Sections 5 concludes the paper and makes some recommendations.

\section{Current situation of renewable energy development in OPEC states}

The growing demand for energy and the issue of climate change have created an increasing awareness of the importance of consolidating renewable energy technologies. Driven by population and economic growth, energy demand has been increasing steadily over the past few years and is expected to continue to grow in the future (Pietrosemoli \& Rodríguez-Monroy, 2019). Building renewable energy is starting to make policies and invest large amounts of funds and resources in a growing number of countries, even in oilrich countries. The development status of renewable energy in different countries varies according to various natural resources, government policies, and energy structures. Renewable energy has been auspicious in some countries, but others have not been successful (Pietrosemoli \& Rodríguez-Monroy, 2019). This section groups OPEC countries into two groups: Middle Eastern OPEC Members and non-Middle Eastern OPEC Members. These groups have nearly similar economic conditions and barriers.

\subsection{Middle Eastern OPEC members}

Some countries like Kuwait and Saudi Arabia had no renewable energy as of 2009; however, Iran and Iraq are just the opposite of them for renewable energy (Romano \& Scandurra, 2014; Almulla, 2014). Most recently, the government of Abu Dhabi has set a goal for its renewable energy policy to generate at least $7 \%$ of its electricity from renewable sources by 2020. Following this suit, Kuwait's government also aims to generate 5\% of its power from renewable sources by 2020 (Reiche, 2010; Mezher, Dawelbait \& Abbas, 2012; Almulla, 2014). Not until recent years, the Middle Eastern OPEC countries have invested and contributed to renewable energy. The UAE has made significant progress, but others have lagged. In fact, the Emirates has the highest proportion of renewable energy in the entire energy mix among the Middle Eastern countries, the researchers find (Atalay et al., 2016). The country designs free trade zones, which is Masdar City, with full foreign ownership and no import duties and taxes to attract foreign investors to invest in renewable energy technology development projects.

\subsection{Non-Middle Eastern OPEC members}


As early as a decade ago, most of the non-Middle Eastern OPEC countries had already generated most of their electricity from renewable sources, such as Angola, Ecuador, Nigeria, and Venezuela (Romano \& Scandurra, 2014; Almulla, 2014). However, despite its considerable renewable and non-renewable energy resources, Venezuela still faces a severe energy crisis (Pietrosemoli \& Rodríguez-Monroy, 2019). Libya, on the other hand, has no renewable energy based on electricity generation; and Algeria has only a few percents of its renewable electricity (Romano \& Scandurra, 2014). Fortunately, Algeria has adopted several policies for the development of renewable energy, embodied in the establishment of a new ministry of environmental and renewable energies (Bouraiou et al., 2019).

In these two groups, we can recognize that there are significant differences in the use of renewable energy technologies in various countries. A large percentage of nonMiddle Eastern OPEC members have adopted renewable energy; however, most of the Middle Eastern OPEC members are lagging. \Although there are examples of effective use of renewable energy for these Middle Eastern OPEC members, they have not actively adopted them.

\section{The possible impact of renewable energy policies in other countries on the transition to renewable resources in OPEC countries}

- With increasing trends in transportation, population, urbanization, and industrialization, the demand for oil from OPEC countries is only growing. As discussed by Almulla (2014), in the short term, fossil fuels are still important, and low natural gas prices will make non-renewable energy demand from OPEC and Gulf countries very attractive for the near-term. In such a scenario, renewable energy policies of non-OPEC countries have the potential to impact the demand for oil from OPEC countries. For example, South Korea imports $85 \%$ of its oil from OPEC at this time, and total demand is increasing by $4 \%$ per year (Almansoori, 2014). South Korea plans to implement robust renewable energy infrastructure to decrease its dependence on petroleum products and to reduce its carbon footprint. However, the lack of private investment in renewable infrastructure has impeded the progress of actually implementing its policy. Almansoori notes that for South Korea, "oil supply from OPEC member countries will remain constant with an annual increase of 1-2\%" (p.581). At the same time, Mezher, Dawelbait, and Abbas (2012) noted that the United Kingdom has significant renewable energy resources; yet has continually lagged behind its true potential and government targets.

These two examples demonstrate that, although non-OPEC countries have renewable energy policies and they are implementing those policies, not all countries have actually achieved a level of sustainability that will significantly lower their oil imports from 
OPEC countries. Therefore, in the short term, there is not an economic factor motivating OPEC countries to shift to renewable energy. However, some OPEC countries have started to implement renewable energy in the short term. Romano \& Scandurra (2014) reported that countries like Angola, Ecuador, and Venezuela generate most of their electricity from RES. Similarly, they assert, Iran and Nigeria generate a significant share of electricity from RES. The authors note that, in contrast, the Gulf and Middle Eastern OPEC members have virtually no electricity generated from renewable sources. One obvious reason is that suchcountries do not offer incentives for renewable investments. The transition to renewable energy in non-Middle Eastern OPEC countries does not appear to be a result of the renewable energy policies in other countries, but instead, as a result of foreign aid tied to renewable energy projects.

For the Middle Eastern OPEC countries, renewable energy policies of other countries will only impact the transition of these OPEC countries to renewable energy if the demand for petroleum products decreases significantly. As pointed out, South Korea plans to transition to renewable energy for $10 \%$ of its energy requirements. If South Korea achieves this and reduces its petroleum demand by $10 \%$, that will grab the attention of OPEC members. But because South Korea and other countries have not been able to achieve their goals; therefore, the overall demand for oil is increasing. As a result, there is no pressure for Middle Eastern OPEC countries to transition to renewable energy.

\section{The possible impact of scarcity of oil reserves on the transition to renewable resources in OPEC countries}

It has been widely understood that crude oil is running out and that the world will soon stop using the non-renewable energy source. However, this seems not entirely accurate, at least in the short- and middle-term. Winter (2015) argues that oil scarcity is artificially produced by oil authorities to keep the price of oil high enough to sustain the industry and to maintain profits. Therefore, the concern on oil depletion cannot be a strong influence for OPEC members in terms of transitioning to renewable energy. In fact, two potential factors increase crude oil availability.

First, crude oil reserves last longer as oil demand growth slows due to an increase in the adoption of alternative energy sources. According to IRENA (2019) and other researchers (Sun et al., 2019), if the global energy transitioning to renewable energy continues, $86 \%$ of electricity generation would be renewable and clean transportation would reach over 1 billion by 2050. This substitution effect of renewable energy will reduce the world's dependency on crude oil. Thus, depending on the development of renewable energy technology and the physical supply of crude oil, oil reserves are unlikely to diminish. 
Another factor is that technological changes increase the availability of crude oil by producing higher output from per unit of crude oil (Smith, 2019). Covert and colleagues also argue (2016that oil is highly unlikely to run out with technological changes. By studying the relationship between technological advances and an increase in oil reserves, the authors found that better technology for oil extraction increased increased the world's proven oil reserves by about 10 percent. In addition, an important additional resource, oil shale, which is known to exist in large quantities, has not yet been commercially developed. According to the US Geological Survey (2006), 2.8 trillion barrels of oil shale exist in the world, that is almost a half percent of the high-end estimate of oil resources. Thus, in the short- and middle-term, the lagged OPEC members are unlikely to adopt renewable energies because the depletion of oil cannot be a significant concern, as the technological innovation leads to an increased availability of crude oil.

\section{Discussion}

This review paper found that significant gaps exist in the adoption of renewable energy technologies in the Middle East and Arab-Gulf OPEC states. Previous research studied the relationship between the adoption of renewable energy technologies and the potential influences for Arab-gulf states. However, few are known on the role of implementation of RE in oil-importing countries and scarcity of crude oil reserves in the adoption of RE among the Middle East and Arab-Gulf OPEC members. The research in this paper confirmed that both the implementation of RE in oil-importing countries and the scarcity of crude oil reserves cannot possibly influence those lagged OPEC states to shift their energy source to renewable energy.

The literature on the adoption of renewable energies has various suggestions for what nations can do to increase clean energy and reduce the use of fossil fuels. Romano and Scandurra (2014) pointed out that incentives for investment in renewable energy infrastructure are critical to the transition to those sources of energy, the lack of which could limit the sustainability of the earth. Mezher and Colleagues (2012) also noted the importance of government policies to encourage renewable energy, including feed-intariffs and a quota system to increase the RE electricity generation.

While the abovementioned solutions might work in non-Middle Eastern OPEC members, they probably would not work in Middle Eastern members, as they respond more to the demand for petroleum products. Thus, I make two suggestions to encourage OPEC countries to transition to renewable energy: one suggestion for the non-Middle Eastern OPEC members and another suggestion for the Middle Eastern OPEC members, to overcome the barriers that cause these countries to lag behind the rest of the world. 
First, the international community should continue to tie economic and development aid to the development and use of renewable energy. This will help these countries to transition to renewable energy and away from petroleum.

Second, the international community should help Middle Eastern OPEC countries develop economic incentives, including guarantees of minimum demand for renewable energy supply and discounted renewable technology, to encourage these countries to transition to renewable energy. Furthermore, the international community can offer other things desired by Middle Eastern countries, like security alliances, military arms, supplies, and favorable trade deals, in exchange for a measurable transition to renewable energy. This will take advantage of the current profit motivation that appears to drive Middle Eastern countries and use it to encourage the development to renewable energy.

This work is relevant to the governments of major developed, western countries and all OPEC members because addressing the lag in renewable transition will require encouragement from outside of OPEC as it will not happen naturally within the OPEC countries in the short-term. 


\section{References}

Almansoori, A. (2014). The influence of South Korean energy policy on OPEC oil exports Energy Policy, 67, 572-582.

Almulla, Y. (2014). Gulf Cooperation Council (GCC) countries 2040 energy scenario for electricity generation and water desalination. Master of Science Thesis. KTH Industrial Engineering and Management. Retrieved from https://www.diva-portal.org/smash/get/diva2:839740/FULLTEXT01.pdf

Atalay, Y., Biermann, F., \& Kalfagianni, A. (2016). Adoption of renewable energy technologies in oil-rich countries: Explaining policy variation in the Gulf Cooperation Council states. Renewable Energy, 85, 206-214.

Bouraiou, A., Necaibia, A., Boutasseta, N., Mekhilef, S., Dabou, R., Ziane, A., Sahouane, N., Attoui, I., Mostefaoui, M., \& Touaba, O. (2019). Status of renewable energy potential and utilization in Algeria. Journal of Cleaner Production, 119011.

Bullis, K. (2013). How Energy Consumption Has Changed Since 1776. MIT Technology Review. Retrieved from https://www.technologyreview.com/s/516786/how-energy-consumption-has-changed-i nce-1776/

Gielen, D., Boshell, F., Saygin, D., Bazilian, D. M., Wagner, N., Gorini, R. (2019). The role of renewable energy in the global energy transformation. Energy Strategy Reviews, $24,38-50$

Covert, T., Greenstone, M., \& Knittel, R., C. (2016). Will We Ever Stop Using Fossil Fuels? Journal of Economic Perspectives, 30(1), 117-138

Institute for Energy Research. (n.d). Retrieved from https://www.instituteforenergyresearch.org/?encyclopedia=fossil-fuels

International Energy Agency (2018). Global Energy \& CO2 Status Report. Retrieved from https://www.iea.org/geco/

International Renewable Energy Agency (2019). Global Energy Transformation. Retrieved from https://www.irena.org/DigitalArticles/2019/Apr/-/media/652AE07BBAAC407 ABD1D45F6BBA8494B.ashx 
Mezher, T., Dawelbait, G., \& Abbas, Z. (2012). Renewable energy policy options for Abu Dhabi: Drivers and barriers. Energy Policy, 42, 315-328.

Pietrosemoli, L., \& Rodríguez-Monroy, C. (2019). The Venezuelan energy crisis: Renewable energies in the transition towards sustainability. Renewable and Sustainable Energy Reviews, 105, 415-426.

Reiche, D. (2010). Energy Policies of Gulf Cooperation Council (GCC) countries possibilities and limitations of ecological modernization in rentier states. Energy Policy, 38(5), 2395-2403.

Romano, A. A., \& Scandurra, G. (2014). Investments in Renewable Energy Sources in OPEC Members: a Dynamic Panel Approach. Advances in Methodology and Statistics Metodoloski Zvezki, 11(2), 93-106.

Šolc, M. (2013). Energy Security - An Important Aspect of National Security. Economics and Management, 1, 82-88.

Smith, C. (2019). The Finiteness of Crude Oil: Are We Running Out? Studies by Undergraduate Researchers at Guelph, 11, 1-9.

Sun, Y., Sun, N., \& Tang, U. (2019). Influence Analysis of Renewable Energy on Crude Oil Future Market. IEEE 3rd International Conference on Green Energy and Applications.

Retrieved from https://ieeexplore.ieee.org/abstract/document/8880778/authors\#authors

Uduma, K., \& Arciszewski, T. (2010). Sustainable Energy Development: The Key to a Stable Nigeria. Sustainability, 2(6), 1558-1570.

Winter, L. (2015). Fueling Oil Scarcity: Produced Scarcity and the Sociopolitical Fate of Renewable Energy. Journal of International Affairs, 69(1), 195-206.

Wittmann, N. (2013). OPEC: How to transition from black to green gold. Energy Policy, 62, 959-965. 